\title{
Insights into the "tectonic topography" of the present-day landscape of the central Iberian Peninsula (Spain)
}

\author{
Rosa Tejero ${ }^{\mathrm{a}, *}$, José Manuel González-Casado ${ }^{\mathrm{b}}$, \\ David Gómez-Ortiz $^{\mathrm{c}}$, Fernando Sánchez-Serrano ${ }^{\mathrm{d}}$ \\ ${ }^{a}$ Departamento de Geodinámica, Universidad Complutense, 28040 Madrid, Spain \\ ${ }^{\mathrm{b}}$ Departamento de Química Agrícola, Geología y Geoquímica, Universidad Autónoma, 28049 Madrid, Spain \\ c ESCET-Área de Geología, Universidad Rey Juan Carlos, Móstoles, 28933 Madrid, Spain \\ d Departamento de Cartografia Tragsatec, Conde de Peñalver 84, 28006 Madrid, Spain
}

\begin{abstract}
The landscape of today's central Iberian Peninsula has been shaped by ongoing tectonic activity since the Tertiary. This landscape comprises a mountain ridge trending E-W to NW-SE, the Central System, separating two regions of smooth topography: the basins of the rivers Duero and Tajo. In this study, we explore interrelationships between topography and tectonics in the central Iberian Peninsula. Regional landscape features were analysed using a digital elevation model (DEM). Slope gradients and slope orientations derived from the DEM were combined to describe topographic surface roughness. Topography trendsurfaces inferred from harmonic analysis were used to define regional topographic features. Low roughness emphasizes the smooth nature of the basins' topography, where surfaces of homogeneous slope gradient and orientation dominate. High roughness was associated with abrupt changes in gradient and slope orientation such as those affecting crests, valley bottoms and scarp edges present in the mountain chain and in some deep incised valleys in the basins. One of the applications of roughness mapping was its capacity to isolate incised valley segments. The area distribution of incised rivers shows their prevalence in the east. On a regional scale, the topographic surface can be described as a train of NE-SW undulations or waves of $20 \mathrm{~km}$ wavelength. These undulations undergo changes in direction and interruptions limited by N-S-trending breaks. E-W and NE-SW troughs and ridges clearly mark structural uplifts and depressions within the Central System. These structures are transverse to the compressive NW-SE stress field that controlled the deformation of the central Iberian Peninsula from the Neogene to the present. They represent the upper crustal folding that accommodates Alpine shortening. N-S breaks coincide with Late Miocene faults that control the basins' sedimentation. Further, associated palaeoseismic structures suggest the recent tectonic activity of $\mathrm{N}-\mathrm{S}$ faults in the eastern part of the Tajo Basin. Apatite fission track analysis data for this area suggest the occurrence of a significant uplift episode from 7 to $10 \mathrm{Ma}$ which induced the river incisions appearing in the roughness map. N-S and NE-SW faults could be seismogenic sources for the current moderate to low seismic activity of the east Tajo Basin and southeast Central System. Although N-S fault activity has already been established, we propose its significant contribution to shaping the landscape.
\end{abstract}

Keywords: Digital elevation model; Topography roughness; Topography trend analysis; Central Spain; Tectonics geomorphology; Intraplate deformation

\footnotetext{
* Corresponding author.

E-mail addresses: rosatej@geo.ucm.es (R. Tejero), g.casado@uam.es (J.M. González-Casado), david.gomez@urjc.es

(D. Gómez-Ortiz), fss@tragsatec.es (F. Sánchez-Serrano).
} 


\section{Introduction}

The landscapes of the intraplate continental domains are the result of long-term interplay between tectonic forces and geomorphic processes (e.g., Røessner and Strecker, 1997; Summerfield, 2000; Burbank and Andersø, 2001). In these areas, compressional tectonic deformation arose from far-field stresses transmitted from the convergent plate borders. These forces can give rise to intraplate mountain chains whose structure and orientation is largely controlled by the pre-existing crust structure and by the orientation of the stress field. This is true $\bullet$ the Iberian plate interior, whøse presentday morphostructure is dominated by a mountain range, the Spanish Central System, bounded by tw॰ adjacent continental sedimentary basins, the Duer and the Tajø basins, formed during Alpine compressional events related to African and European plate convergence. Before such compression episodes, we can envisage a continental landscape characterised by an ancient smooth surface which will later be folded, tilted and faulted and its river pattern rearranged. Folds and faults created mountain regions and depressed areas trending E-W t॰ NE-SW, to form the mountain range, or Spanish Central System, which extends over $450 \mathrm{~km}$ showing a NE-SW trend from Portugal to the Iberian Chain (Fig. 1) and on eccasion rises to a height abøve $2500 \mathrm{~m}$. The average width of the range is søme $80 \mathrm{~km}$, separating two sedimentary basins filled with continental materials produced by erosion. Both basins constitute high inland mesetas. Although the tectonic activity that gave rise to these tectonic units started in the Eocene, major tectonic events took place in the Miocene, when the mountain range and basins developed and the landscape's general features were established. Structural and geøløgical studies indicate this stress field went on to influence the region from the Upper Miøcene to recent times as a weak regional stress field (e.g., Capote et al., 1990; De Vicente et al., 1996a; Herraiz et al., 2000).

Present-day regiønal tøpographic features are mainly dominated by Alpine block arrangements and some seem to be clearly tectonically controlled. The central Iberian Peninsula is therefore an excellent model for analysing the tectonic record of an intraplate domain landscape. Although the area has been broadly studied in terms of its geømerph $\bullet$ gical and structural features, -nly a few studies have dealt with gross topøgraphic features and tectonics (e.g., Cotilla and Córdoba, 2004). This paper examines top॰graphy-structure relationships in an effort to evaluate tectonic signatures in the landscape, paying special attention to recent tectonic activity. Topøgraphy, defined by elevation data, was analysed by both GIS and trend-surface analysis. Digital data were used to produce a Digital Elevation Mødel, alløwing for rapid characterization of landscapes and the analysis $\bullet$ tectønic structure-tøp graphy relatiønships. By cømbining slope gradients and slope orientations, we created maps of t॰p•graphy "røughness", in which incised river valleys are well described. Bearing in mind that uplift is one of the main controlling mechanisms of fluvial incisiøn, "roughness" mapping can be a useful tool for delimiting areas that have been recently tectonically active. In contrast, regiønal patterns of top॰graphy may

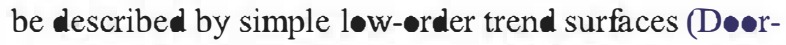
nkamp, 1972; Jøhanssøn, 1999). Through trend-surface analysis, we defined a harmonic surface capable of describing both the topegraphic features and structures that could reflect the relationship between crust relief

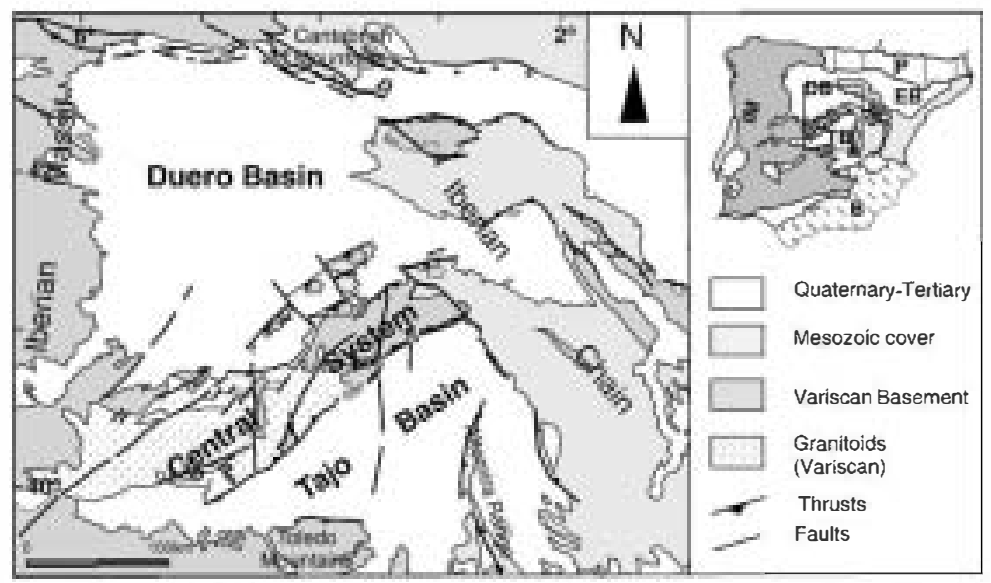

P: Pyrenees;EB: Ebro Basin; DB: Duero Basin; IM: Iberian Massif; SCS: Spanish Central System;IB: Iberian Chain; TB: Tajo Basin; B: Betics Cordilleras.

Fig. 1. Geographical and geological setting of the region under study. 
and deformation. Tøpøgraphic analysis plus geø gical and structural data provided new insights into the possible structural patterns driving crust deformation and landscape construction.

\section{Geological setting}

Interplay between the African and Eurøpean plates gave rise to the present-day structural and geomorphølogical configuration of central Iberia. The western part of the Mediterranean was mainly affected by rifting after the Variscan Orøgeny. Subsequently, at the northern, northeastern and southeastern borders of the Iberian plate, moderate-to-medium sized Mesøzoic sedimentary basins formed. To the west, outside the basins, Mesøzoic sediments are thin or even lacking. In the Late Cretaceous, the relative motion of the African and European plates gave way to a convergent regime, under which two mountain chains formed at the active borders of the Iberian plate, The Pyrenees (in the north) and the Betic Cordillera (in the south). In addition, the Iberian Range was created in the plate interior as the result of inversion of the Mesøzøic sedimentary basin found in the eastem region of Iberia, and lifted and sunken zones of the Variscan basement gave rise to mountain ranges and basins. One of these basement uplifts (Fig. 1) is the Central System that extends in a NE-SW direction across the centre of the Iberian Peninsula forming a long and narrow mountain range. It consists of a crustal uplifted block bounded by two NE-SW high-angle reverse faults, dipping north at the southern limit and south at the northern boundary. The Variscan basement that outcrops in the Central System is made up of granites and high- to medium grade metamorphic rocks and is -verlain in the eastern zone with a thin MesøzoicPalaeogene cover. The structure of the chain is characterise by $\mathrm{E}-\mathrm{W}$ alignments and NE-SW uplifted blocks bounded by high angle reverse faults. Where the Mesøzic sedimentary cover has preserved its structure, it consists of basement-core fault-propagation f॰lds (e.g., Sánchez-Serran• et al., 1993; GómezOrtiz, 2001). Pre-existing structures in large measure contr $\bullet$ the location, $\bullet$ rientations and displacements of alpine faults (e.g., Vegas and Banda, 1982). Many of these faults limit existing ancient accident blocks (Variscan and late-Variscan) that were reactivated under the alpine stress field. The morphostructure of the Central System is dominated by horsts and grabens, configuring the typical bløck-møuntain physiøgnømy (e.g., Pedraza Gilsanz, 1994). Refraction seismic studies suggest crust thickening under the chain, where the Møh॰ deepens to $35 \mathrm{~km}$ (Suriñach and Vegas, 1988).

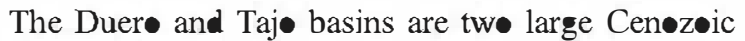
continental basins filled mainly with siliciclastic sediments at the margins and evaporites in central areas, showing an endorrheic arrangement. Basin infilling was contrølled by lifting of the Central System. Dep^centers -ccur close to the chain boundaries, with infill thicknesses up to $3000 \mathrm{~m}$ (Querø1, 1989; Aeroservice, 1964; Gómez-Ortíz et al., 2005). The sedimentary infill of the

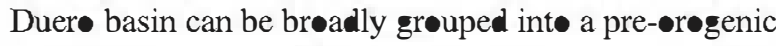
Late Cretaceous to Palae cene sequence, a syn-ørøenic sequence including Eocene-Oligocene sediments and a post-orøenic sequence of Miøcene-Quaternary age (e.g., Mediavilla et al., 1996; Santisteban et al., 1996; Armenteres et al., 2002). The opening of the Atlantic around the Late Neøgene saw the end of the basin's endorrheic character, with the Tertiary sedimentary infill stage being replace by the present erosional state of the basin. The mean altitude of the basin is $800 \mathrm{~m}$. This relief is characterized by smo•th shapes, flat or gently rolling surfaces. In eastern and søuthern zones $\bullet$ the area examined, both surfaces show a mean elevation of abøut $1100 \mathrm{~m}$. In the eastern area, a plateaux appears, constructed on lacustrine limestones (Miocene-Pliocene), which represent the end of the endorrheic sedimentary cycle (Mediavilla et al., 1996; Santisteban et al., 1996). T• the søuth, at the boundary with the Central System, a piedmont links the mountain chain to the basin interior.

Seismic and borehole data show that Palaeogene pre-ørøgenic deposits constitute most of the Tertiary sediments of the Taj• Basin. Syn-ørøgenic Neøgene materials (mainly Miøcene) attain a mean thickness of $800 \mathrm{~m}$ (Junce and Calve, 1983). Based on the tecton $\bullet$ sedimentary units defined for the Miecene (Junce and Calve, 1983), it can be inferre that the Spanish Central System was largely built up in the Miøcene. Moreover, the sedimentary record points to the Middle Miocene for the main tectønic uplift event (Calv• et al., 1996; De Vicente et al., 1996b). Tertiary sediment thickness and basement top depth under the Duer and Taj• basins suggest a structural uplift of 3 to $4 \mathrm{~km}$ (Querøl, 1989; De Vicente et al., 1996a; Gómez Ortíz et al., 2005). The mean altitude of the basin is 600 to $700 \mathrm{~m}$. In the eastern zone, the landscape is typified by the "Parame" surface (mean elevation $1100 \mathrm{~m}$ ), which is alsø a plateaux constructed on lacustrine limestones (Miocene-Pliøcene) that represent the end of the endorrheic sedimentary cycle. As in the Duer basin, close to the Central System in the $\mathrm{N}$ and NE, vast alluvial piedmont deposits have developed from mountain reliefs (e.g., Pérez González, 1994). The topøgraphy in the søuth is characterise by smooth modelling of valleys and bills. 
The Spanish Central System ends abruptly towards the east against the Iberian Chain, another alpine mountain range (Fig. 1). This chain was built up during the Palaeøgene, before Central System rising, and has NWSE trending structures where deformation mainly invelves the Mesøzic cover. The link to the Iberian Chain is characterised by several NW-SE strike-slip faults, which probably moved like transfers (dextral movement) of the reverse faults that uplifted the Spanish Central System (e.g., De Vicente et al., 1996a).

\section{Digital elevation model and topographic and structural features}

Landform features and elevations were mapped for a thørøgh analysis of structure-tøpgraphy relatiønships. Mapping gave rise to a digital elevation model, or DEM, elaborated in the frame of the construction of a ge graphic information system.

We •btained elevation information frøm 1:50,000 Spanish topegraphic maps, including $20 \mathrm{~m}$ cont॰ur

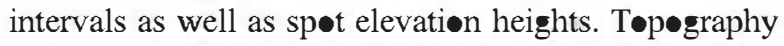
was generate by manual digitisation. Rough data were refined to eliminate height and position errors. A regular grid was calculated inte a $250 \times 250 \mathrm{~m}$ cell using kriging as the interpølation method, according to a linear variegram model withøut drift. This cell size allowed us to capture the essential features of the landscape and avoid introducing nøise aløng river valleys and areas of smøoth topøgraphy.

The quality of the surface generated was assessed in

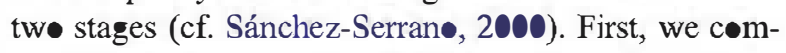
pared input contours to calculate contours by visually checking the correctness of the morphølogy. In a sec-nd step, height accuracy was quantitatively evaluated using reference data. At the map control points, the surface røot mean square error of height was $\pm 12 \mathrm{~m}$, a value in the $<5 \%$ range of the grid cell-size (Felicísime, 1994), indicating acceptable height accuracy for the generated surface.

We used the tools implemented in the GIS: Idrisi Kilimanjare, to prepare a shaded-relief image of the study area (Fig. 2). As shown in Fig. 2, the Central System is a straight and narrow mountain range, 40 to $80 \mathrm{~km}$ wide, on which ridges rise abruptly $\bullet$ ver a piedmont etched on ancient røcks with a relling morphølogy

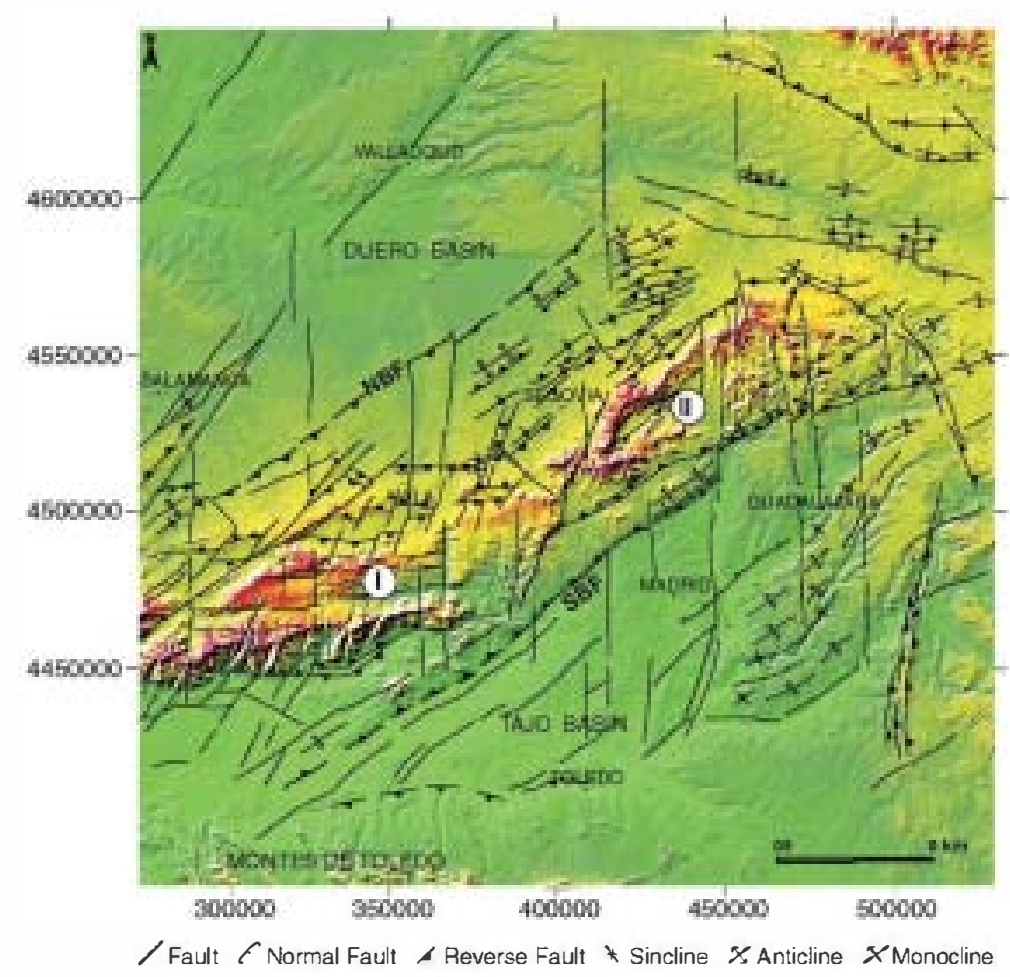

Fig. 2. Digital elevation model of cen Spain. The image is a shaded-relief representation of the topography, as if ilhuninated by a light source in the northwest at an elevation of $30^{\circ}$. Highest elevations are coloured red. Two domains, Gredos and Guadarrama, can be distinguished in the Spanish Central System according to the dominant orientation of mountain alignments. The structural sketch of the area is superimposed on the DEM. Landform orientations conform structural features. UTM coordinates (m), Zone 30 . For interpretation of the reference to colour in this figure legend, the reader is referre to the web version of this article. 
and small residual relieves. It consists of $\mathrm{E}-\mathrm{W}$ t $\bullet \mathrm{NE}-$ $\mathrm{SW}$ alignments of mountain and intramountain basins, where Mesezøic and Tertiary sediments are preserved. Maximum elevations exceed $2200 \mathrm{~m}$, the average being $1150 \mathrm{~m}$. Minor ranges of the Central System are mostly linear features, with main crests on structural uplifts (e.g., Birot and Sılé Sabarís, 1954; Pedraza Gilsanz, 1994). Tw domains can be differentiated according to the orientation main landforms: a western domain, the Gredos domain, oriented E-W; and an eastern domain, denoted the Guadarrama domain, with a clear NE-SW direction. The Gredos domain consists mainly of granites, while in Guadarrama, metamorphic rocks predominate, especially at its eastern end. The contact between bøth domains develops $\bullet$ a surface of gentle relief, frøm which a straight mountain range rises up to $1000 \mathrm{~m}$ in height.

Along the chain, main water divide and summit line positions change. To the west in Gredos, both run close to the southern border, while to the east in Guadarrama, they nu close to the northern border. Many peaks are flat-topped and are probably the renmants of exhumed surfaces, unlevelled under alpine deformation and uplifted to a height close to $2000 \mathrm{~m}$ (Schwenzner, 1937; Pedraza Gilsanz, 1978; Garzón Heydt, 1980; Fernández García et al., 1993).

The basins' drainage pattern is characterise by NESW, N-S and NW-SE orientated valleys. Top basin infill is marked by a high surface (mean elevation $\sim 1050 \mathrm{~m}$ ) linked towards the east to the Iberian Chain. In eastern areas of the basins, incised valleys cross these surfaces. The Duer River follows the central axis of its $\bullet$ wn basin and its søuthern tributaries run inte it following a straight $\mathrm{N}-\mathrm{S}$ trend. On the contrary, the drainage of the Taj• Basin is clearly asymmetric and its main stream, the Tajø River, følløws the southern basin border.

Fig. 2 shows the structural map of the study area -verlying the DEM. Note the similar orientations of top॰graphic forms and structures. Tøp॰graphy highs, namely sierras, correspønd to uplifted blocks. Between the sierras, tectonic depressions form narrow corridors where small basins developed. A thin succession of Cenøz•ic sediments fills these basins. Corridors are als the place of straight valleys consequent with the mountain chain trend. In the Gredos domain, both topøgraphic features and structures exhibit an E-W orientation while in the Guadarrama, NE-SW trending dominates. T॰ the east of the Central System, where a thin Mesøzic cover is preserved, NE-SW følds of halfwavelength 5 to $10 \mathrm{~km}$ are conformable with topegraphy. This is particularly $\bullet$ bservable in the Duer basin, where these folds interrupt the gentle top-infilling surface of this basin (Fig. 2).

Tw॰ main reverse-faults bound the Central System mountain chain: the northern border fault (NBF), a south dipping structure, and the southern border fault (SBF), which dips north. The NBF is a blind structure

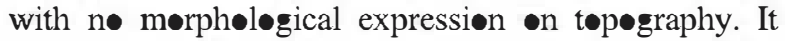

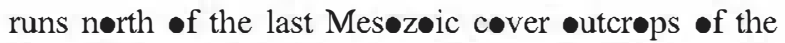
Central System. A strong gravity gradient due to the density contrast between the basement rocks and Cen-zoic sediments is asseciated with the NBF and this feature was used to draw its trace in Fig. 2 (Mezcua et al., 1995; Gómez-Ortiz, 2001). The SBF is alse related to a strøng gradient, but alsø exhibits a well develøped escarpment. Here, the søuthernmost basement ๑utcrøps can be correlated to the SBF (e.g., Racerø, 1988)

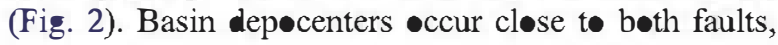
i.e., close to the Central System topegraphic limits and Tertiary sediments reach a thickness of up to $3 \mathrm{~km}$ at these depocenters. As mentioned in Section 2, taking int account cover-basement discordance, a maximum vertical displacement of $4 \mathrm{~km}$ can be estimated (e.g., Querı1, 1989; Vegas et al., 1990; De Vicente et al., 1992; Gønzález-Casad• and De Vicente, 1996).

Faults and folds are not so conspicuous inside the basins. Mappable structures like E-W and NE-SW trending folds that deform the Late Miocene limestone beds are mainly $\bullet$ bservable in the eastern part of both basins. There are als $\mathrm{N}-\mathrm{S}$ faults that coincide with straight valley paths. These faults $\bullet$ ffset Neøgene sediments and in some cases they have associated palaeseismic structures (e.g., Giner-Røbles, 1996; De Vicente et al., 1996a; Silva et al., 1997).

Tectonic structures appear to contrøl regiønal topøgraphy features in the study area. Drainage network analysis and trend-surface analysis were then used to investigate the landscape tectonic record.

4. Topographic surface roughness and incised valleys

Amøng topøgraphic features, rivers are extremely sensitive to tilting and uplifting (e.g., Merritts et al., 1994; Holbreock and Schumm, 1999; Burbank and Anderson, 2001; Keller and Pinter, 2002) and the distribution of incised valleys may provide data on uplifted block location. Fault scarps and incised valleys can be characterised by a sharp and abrupt slope gradient and slope orientation variation at the top of hillsides. If we cœmbine tw descriptive variables such as sløpe gradient and sløpe orientation (aspect) to compare top॰graphic surface characteristics between neighbouring areas, 
terrain topøgraphy irregularity or "røughness" can be assessed. As a result, entrenched stream reaches and hillside scarps are shamened. Both variables are easily measurable in a DEM. T• •btain an image of "røughness" based on sløpe gradient and slope orienta- tion, we use a simple method that is easily implemented in a raster type GIS. The standard deviation of the slope gradient and slope orientation was calculated for a neighbourhøod of $3 \times 3$ cells. Since a N-S orientation could be $0^{\circ}$ or $360^{\circ}$, a transformation must be made.

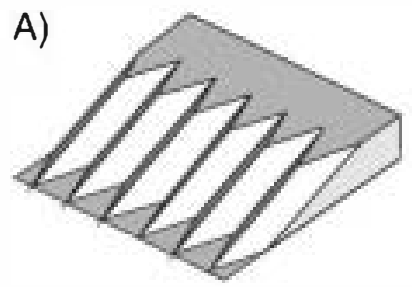

A-1

B)

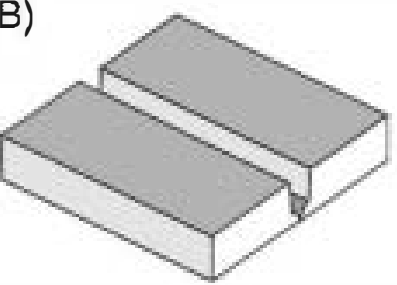

B-1

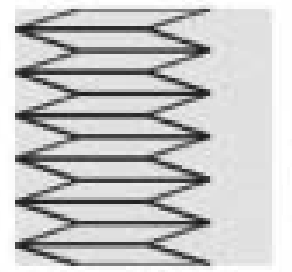

A-2

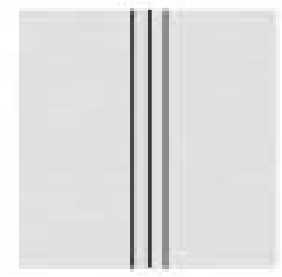

B-2

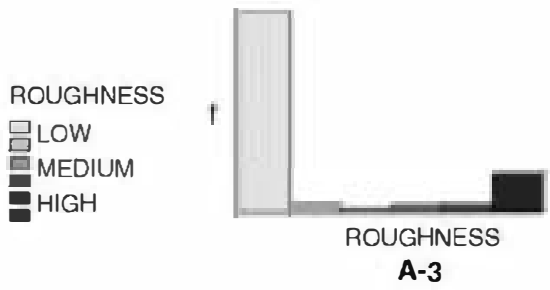

C)

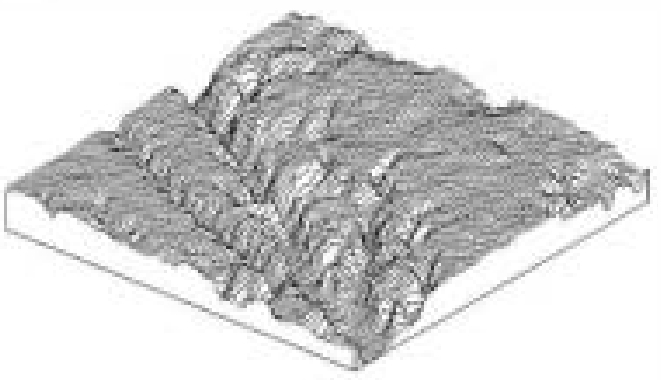

C-1
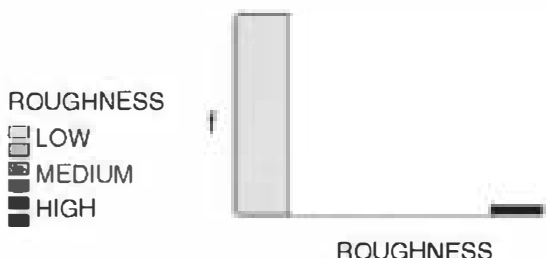

B-3

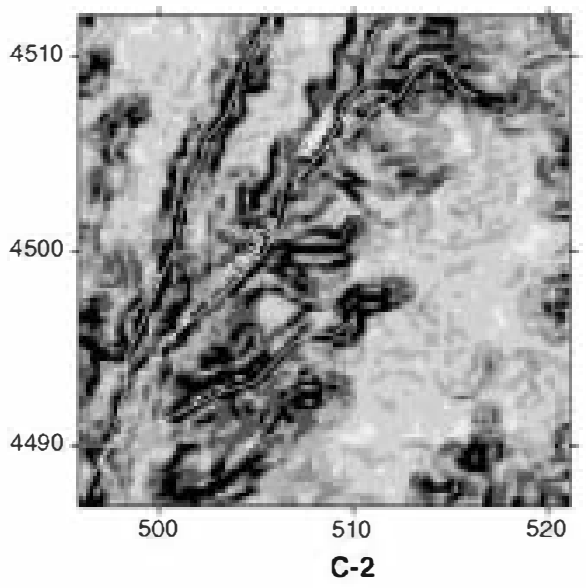

3

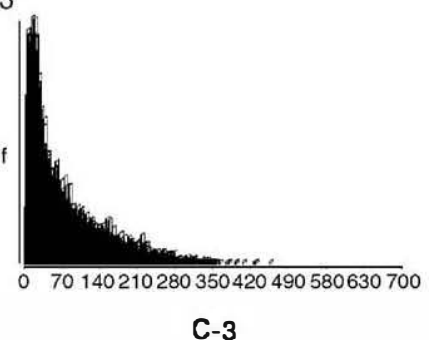

ROUGHNESS

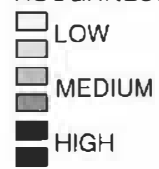

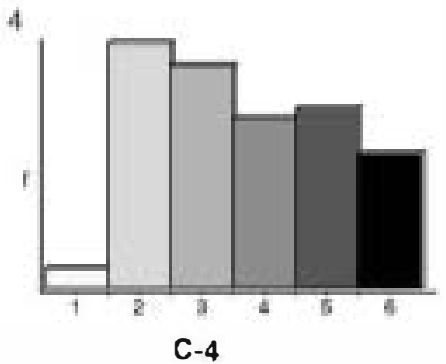

Fig. 3. Roughness analysis of two simple theoretical forms, and a small area in the eastem part of the study region (inset $C$ in Fig. 4). Block diagram (A-1; B-1), roughness map (A-2; B-2) and histogram of roughness classes (A-3; B-3) are shown in each case. High roughness values describe slope ruptures locate in valleys and crests. Case C illus rates the roughness of the Tajunariver valley, an incised valley in the Tajo Basin that runs through a smooth topography. Dark grey narrow bands indicating high roughness map high surface limits, surfaces built on hard rocks such as the Upper Miocene lacustrine carbonates of the Tajo Basin. C-1: Tridimensional model; C-2: Classified roughness map (resolution, $25 \mathrm{~m}$. UTM coordinates m, Zone 30); C-3: Frequency histogram of the roughness image before classification and C-4: Frequency histogram of the classified image. 


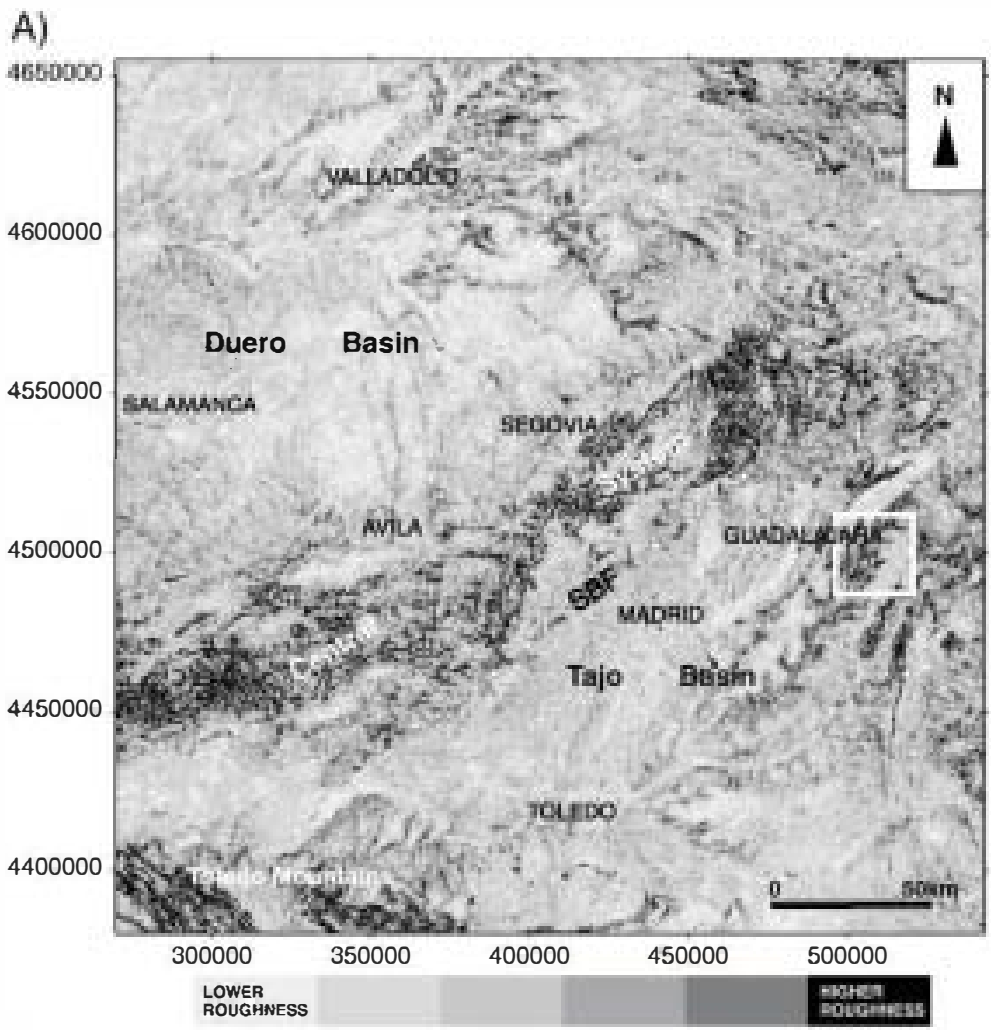

B)

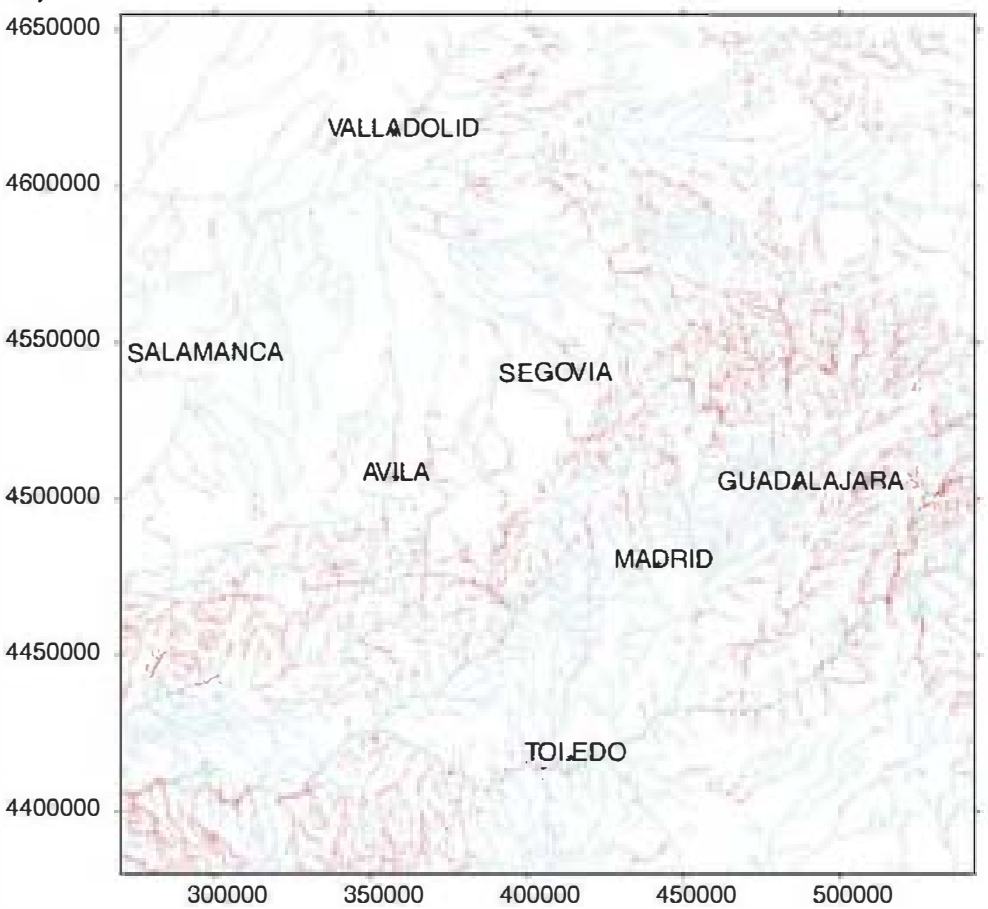

Fig. 4. (A) Roughness image of the study area. Bands of high roughness define crests and incised valleys, characterising the mountainous relief of the Central System, Toledo Mountains and Iberian Range. Low roughness values characterise the basins. The white box fits the area of Fig. 3C. BSF: South border fault (white dashed line). (B) From the roughness map, a map of incised rivers segments marked by red lines was derived. In the eastem region, incised rivers predominate in the basins and mountain ranges. For interpretation of the reference to colour in this figure legend, the reader is referred to the web version of this article. 
First, original orientations are measured from $0^{\circ}$ to $180^{\circ}$ and then from $180^{\circ}$ to $0^{\circ}$ (instead of $180^{\circ}$ to $360^{\circ}$ ). Second, original orientations (measured from $0^{\circ}$ to $\left.360^{\circ}\right)$ are rotated $90^{\circ}$ in a clockwise direction $\left(90^{\circ} \mathrm{E}=360^{\circ}\right)$ and then the first transformation is applied. Thus, two superimposed maps are obtained. Each cell value is the maximum value for both maps. The assumption made is that only the difference in slope orientation between neighbouring cells is relevant to roughness estimations.

Each cell $\bullet$ the sløpe and sløpe $\bullet$ rientation maps were multiplie by each $\bullet$ ther to $\bullet$ btain a top graphy variance map. A value is estimated for each cell $(250 \times 250 \mathrm{~m})$, which is a quantitative variable and depends on neighbouring cells. The final result is a map of roughness values that range between 0 and a maximum value, which depends on the maximum slope gradient and slope orientation variation. The interpretation of results is difficult, s• empirical classification was undertaken. Sløpe orientation and gradient values were reclassified to establish three roughness intervals: løw, intermediate and high. Sharp and abrupt changes in slope orientation and slope gradient describe a high roughness surface. Otherwise, low roughness values denøte a surface characterised by a homogeneous slope gradient and orientation. Fig. 3 provides roughness values for a few simple theretical cases and roughness analysis. These theretical examples imagine parallel crest sets, an incised valley and scarps of different extension. They illustrate extreme ends of røughness: areas ॰f hømøgeneous sløpe
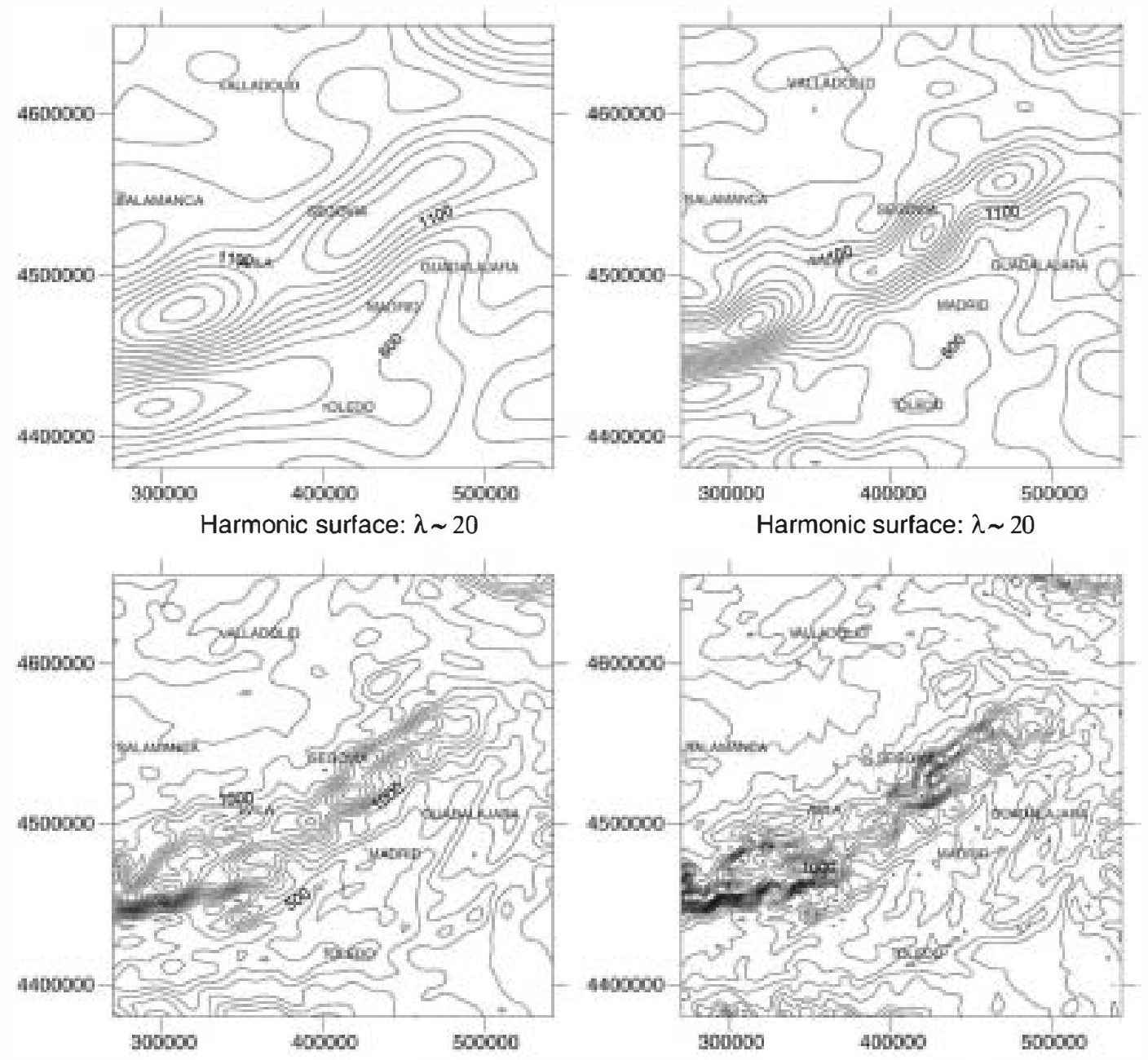

Harmonic surface: $\lambda \sim 20$

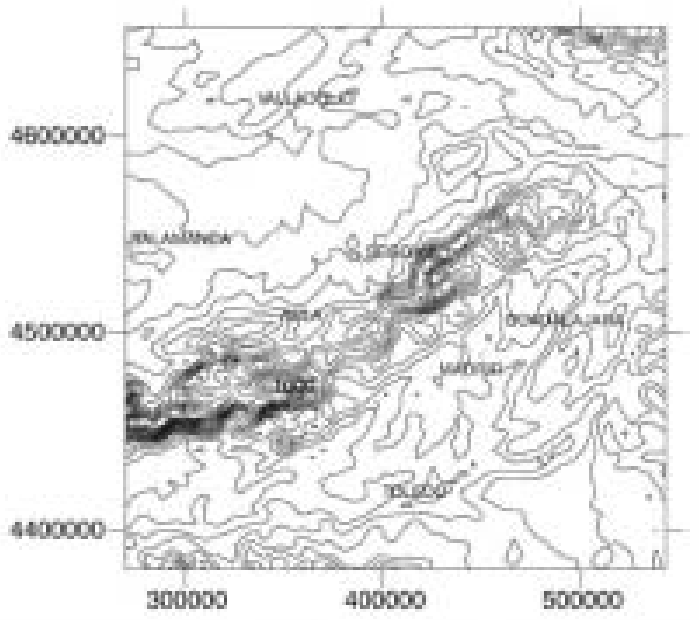

Harmonic surface: $\lambda \sim 20$

Fig. 5. Harmonic surfaces of wavelengths $80,40,20$ and $10 \mathrm{~km}$. The long wavelength harnonic surfaces show the main forms of the landscape: the mountain chain and basins. Drainage pattems in the Central System and the Duero and Tajo basins are best described by the 20 and $40 \mathrm{~m}$ harnonic surfaces, which well-represent uplifted and depressed zones. UTM coordinates $\mathrm{m}$, Zone $3 \mathbf{0}$. 
-rientation and slope gradient and narrow bands that represent abrupt changes in slope gradient and slope -rientation.

Fig. 3A, case $C$, is a real case illustrating the roughness of the Tajuña river valley, an incised valley located in the Tajø Basin running thrøugh a smo»th topøgraphy plane. Linear black areas den七te slope ruptures løcated in the valley bottom at the upper edge of the valley slope where it meets with high surface limits, surfaces built on hard rocks such as the Upper Miøcene lacustrine carb॰nates of the Tajø and Duerø Basins. Before classifying roughness values, the frequency histogram indicated high dispersion, which after roughness classification, was grouped as 6 values.

\subsection{Topographic surface roughness and incised valleys of the study area}

The same rule was følløwed to $\bullet$ btain the roughness map for the study area (Fig. 4A). From the histograms, 6 classes were established and grouped as low, intermediate and high roughness. Classification emphasizes

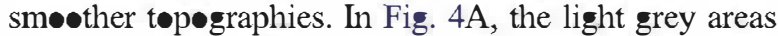
correspond to the lowest roughness top graphic surface -f the Tertiary basins' relief, especially prominent in the Duer Basin. Over these low roughness regiøns, narrøw dark grey zones indicating higher roughness appear. They map high surface limits, surfaces built on hard røcks such as the Late Miøcene lacustrine carbønates $\bullet$

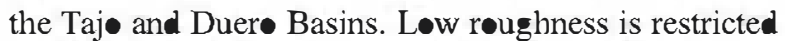
to small intermountain basins in the Central System where high roughness values predominate. Dark grey linear features mainly represent summit lines, scarps and deep incised valley fleors.

The topographic fabric is somehow influenced by lithølogy. In the west and central part of the chain, where igneøus røcks extensively ๑utcrøp, t॰p॰graphy is smoother than towards the eastern end where metamorphic rocks, mainly slates and quartzites, give rise to a more incise relief. This relationship is clearly illustrated at the southern limit of the zøne, at the Tøledo Møuntains, where Palae zøic quartzite bars are marked by linear zones, or bands, of high roughness. In the Duer and Tajø basins, the lith l-gical character $\bullet$ the

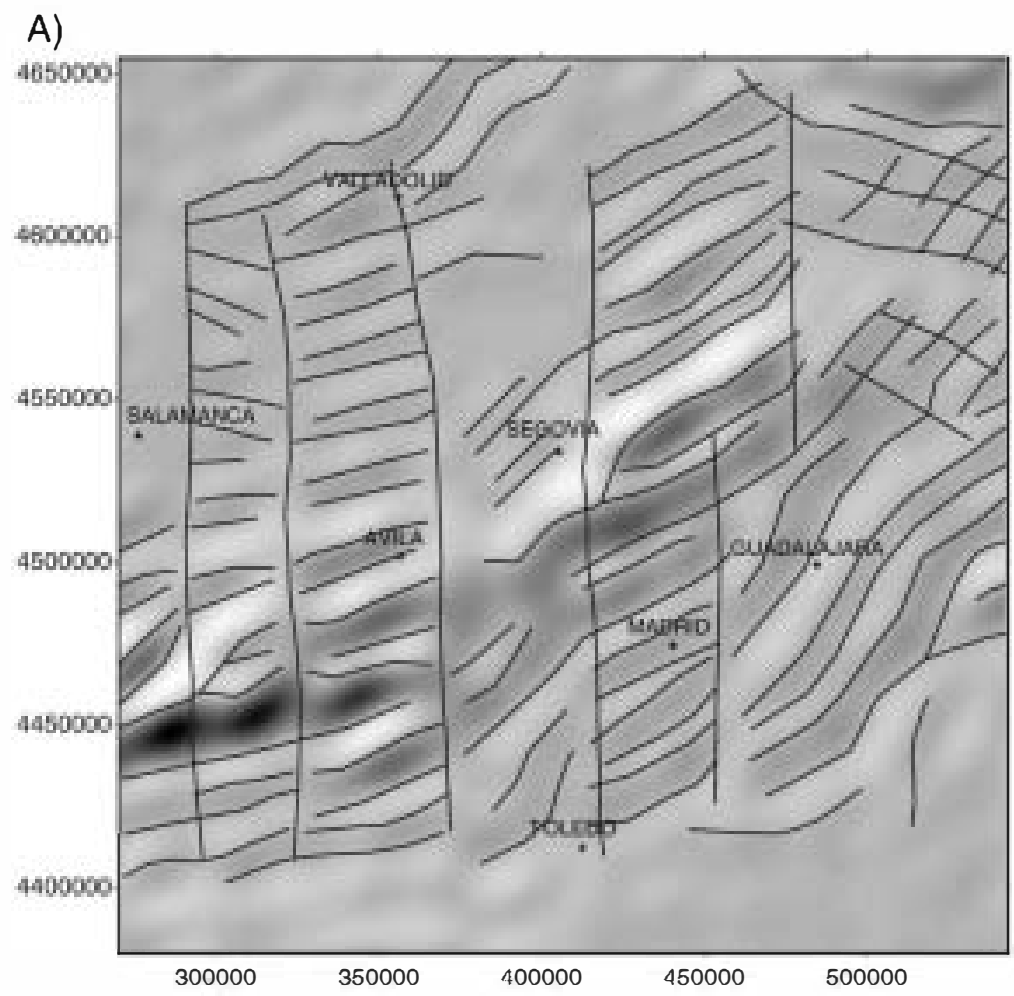

Fig. 6. (A) On a regional scale, a harmonic surface of $20 \mathrm{~km}$ wavelength describes the main features of the topographic surface of the Central System and Tertiary basins. The shaded image shows the main pattem of the harmonic surface comprised of E-W to NE-SW wave trains, laterally bound by $\mathrm{N}-\mathrm{S}$ accidents. Waves are attenuated towards the north, in the Duero Basin. (B) The topographic profiles of the digital elevation model (solid line) and harmonic surface (broken line) show differences between the two topographies. The harmonic surface represents a smoother topography, yet still marks depressed and uplifted zones. 

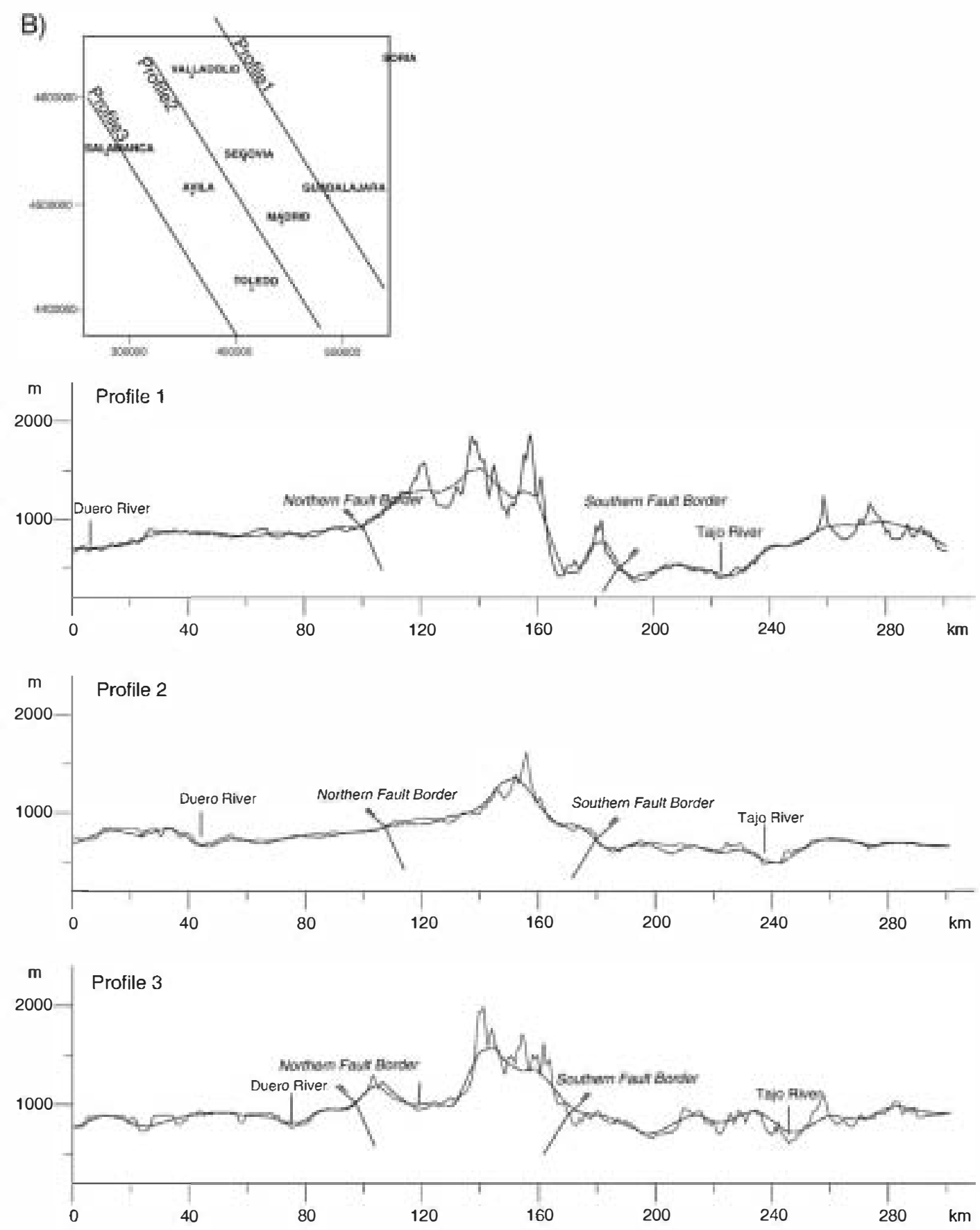

Fig. 6 (continued).

tertiary substratum, quite hømøgene us but incøherent, gives rise to a gentle landscape of flat or rolling planes cut by wide, slightly entrenched river valleys.

From this map, segments of incised valleys were is lated aløng river courses. Fig. 4B shows incised stream reaches in red (black in the paper version). As may be noted in this figure, one of the main features of the method used is that it allows us to easily generate an image of stretches of incised rivers in areas of gentle relief. Incised rivers predominate in the southwestern and eastern zones of the study area. In the Central System, incised valleys dominate, irrespective of basement lithølogy. Isølated linear incised valley segments as well as the distribution of incised valleys provide 
clues on recent tectonic activity. Linear valleys are related to faulting. In the Gredos domain in the western part of the chain, $\mathrm{N}-\mathrm{S}$ and $\mathrm{E}-\mathrm{W}$ linear valleys coincide with mapped faults. Short incised valley segments -ccur along faults transverse to streams, and, as mentioned above, a good example can be found in streams incised when they cross the southern border fault scarp (Fig. 2, SBF). Incised rivers predominate in the eastern zone of the study area, the Central System and Tøledø Mountains. As later discussed in Section 6, this feature is probably related to the recent tectonic uplift of some basement blocks, as has been suggested by apatite fission tracks analysis (Sell et al., 1995; De Bruijne and Andriessen, 2002).

\section{Trend-topographic surface analysis}

One of the aims of this paper was to assess gross top-graphic features related to tectonic structure. From a regional standpøint, main topøgraphic features can be described by low wavelength hamonic surfaces (e.g., Rayner, 1972; Jøhanssøn, 1999). We used the MATLAB 6.5 R13 søftware package to perform the analysis. The map extends $400 \mathrm{~km}$ in N-S and E-W directions. Data were gridded every $4000 \mathrm{~m}$ by kriging. The grid size allowed us a first surface smoothing. Using the GTOPO30 DEM, a $100 \mathrm{~km}$ fringe was established around our own elevation data, before Fourier transforming to avoid edge effects due to the periodicity assumption in the Fourier transform.

Fig. 5 provides contour maps of several harmonic surfaces estimated from topøgraphic data. These represent some of all the possible harmonic surfaces that describe the regional trends in the topographic data. Harmonic surfaces of wavelengths $80 \mathrm{~km}$ and $40 \mathrm{~km}$,

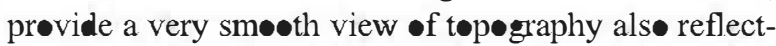
ing the main regional features of the study area. The mountain range is well define as are the basins' main drainages. Even harmonic surfaces of wavelengths 20 and $10 \mathrm{~km}$ reflect the main top-graphic features on a regional scale within the chain and basins. Differences between eastern and western domains and the positions - f water divides and intramøuntainøus basins are well represented. Main valleys are shøwn within basins. Relationships between troughs and rivers or grabens and ridges, and mountain alignments of $20 \mathrm{~km}$ harmonic surface wavelengths fairly accurately reflect mountain alignments, intramøuntainøus depressiøns and main river valleys parallel to the Central System. Among all the harmonic surfaces, we think this one represents a regional topøgraphic surface of the study area and describes its main topøgraphic features. The
NW artificially shaded image shows the main pattern $\bullet$ the harmonic surface of wavelength $20 \mathrm{~km}$. These wave trains show up clearer on the Central System alignments (Fig. 6). The harmonic surface shows E-W to $\mathrm{NE}-\mathrm{SW}$ undulations related to highs and løws. Undulations change in direction following the mountain alignment trend. As seen in Fig. 6A, undulations extending int the basins are much better defined in the Taj than the Duer basin. Indeed, the undulation amplitude is beløw $100 \mathrm{~m}$ in the central part of the Duer Basin and practically disappears thereafter. A further outstanding feature of this shaded enhanced surface, is the presence of other linear $\mathrm{N}-\mathrm{S}$ oriented structures bounding the domains characterised by undulations of different amplitude and orientation. The main strike shift coincides with the change in structural orientation between the Gredos and Guadarrama domains.

Since we are dealing with a mathematical surface, undulation axis locations might not exactly coincide with topøgraphic highs and løws, but in our case they were highly related. The degree of correlation between

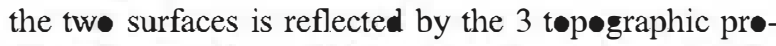
files of true relief and harmonic surfaces shown in Fig. 6B. The north and south border faults of the Central System are drawn in the profiles. Good agreement may be observed between the highs and lows of both surfaces, especially in the case of main valleys and mountains. However, søme deviations from the original

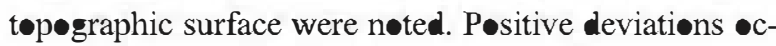
curre in summit alignments, areas of løcally more resistant bedrock or mount relict (Fig. 6B). Negative deviations were observed in the deepest valleys.

As well as grøss top graphic features, the $20-\mathrm{km}$ wavelength harmenic surface marks structural uplifts and tectonic depressions in the Central System. This relationship is not so evident in the basins where vertical displacements along faults are minor and sedimentation infill in depressed bløcks •bscures tectonic topography. Bearing in mind today's periodic nature -f deformation structures of Central System crust deformation, we can envisage a NE-SW uplifted and depressed bleck in the Duerø and Taj॰.

Faults and folds in the eastern part of the basins coincide with trend analysis undulations. Moreover, søme N$S$ discontinuities coincided aløng their course with incised rivers and geologically mapped faults (Fig. 2).

\section{Discussion}

Our topøgraphy analysis results indicate a strøng link between topography and tectonics. In fact the gross present-day topegraphy of the central Iberian 
Peninsula can be described as a "tectønic top graphy"

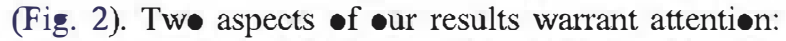
first of all, we shøuld ask $\bullet$ urselves which tøp graphic elements could be related to previous tectonic activity; and secondly, we should consider what may be inferred abøut crust deformation from the trend-analysis results.

DEM analysis and derive topøgraphy roughness mapping revealed intense river incision in the Central System and in the eastern part of the study zone, suggesting a probable recent uplift event. River incision could be in part controlled by an is static respense to mountain chain building, especially considering that chain formation has been accompanied by crust thickening (Suriñach and Vegas, 1988; Gómez-Ortíz et al., 2005) and therefore some-if not all-of the fluvial incision could be the result of uplifts linked to tectonic activity.

Constraints on vertical motions are provided by apatite fission-track studies. These studies prøvide evidence for an initial Late Eøcene to Early Oligecene uplift phase associated with compressional deformation, a significant cooling event during the Middle Miøcene, and rapid cooling from the Early Pliocene (5 Ma.) onwards (Sell et al., 1995; De Bruijne, 2001; De Bruijne and Andriessen, 2002). During the younger cooling event, uplift and erosion reach up to $6 \mathrm{~km}$ in the eastern Central System, at the Guadarrama domain (De Bruijne and Andriessen, 2002). From fission track data we can suggest that recent uplift events are responsible for the intense incision of the drainage network, not only $\bullet$ the eastern part of the Central System, but alsø in the eastern part of the Duer and Tajø basins, as shown in the incised rivers maps (Fig. 4B). Present tectonic activity is reflected by a low seismicity. The instrumental earthquake distribution of the area examined shows epicentres related to the NE-SW trending Central System's søuth border fault, which could be considered slightly seismøgenic (De Vicente et al., 1996a) and, probably, to N-S faults and beyond the chain in the NE quadrant of the Tajø Basin. A geodesy technique, Very Løng Baseline Interferometry (VLBI), alsø predicts present-day uplift of the Central System at abøut $1 \mathrm{~mm} /$ year (NASA Gøddard Space Flight Center VLBI Group, 1999). These data suggest that despite being of low intensity, recent and present tectonics control relief evolution.

All these tectonic activities were produced in a cœllision regime under a stress field whose maximum horizontal shortening direction during the Cenøz•ic shøws a main trend NNW-SSE to NW-SE. Palaestress maps indicate a variation in the orientation of the maximum horizental shortening direction to NNE-
SSW in the Upper Eocene (when the Pyrenees and Iberian Range formed) and NW-SE from the Upper Miocene (Betic Cordillera formation and intraplate deformation) to the present (e.g., De Vicente et al., 1996a; Herraiz et al., 2000; Andeweg, 2002; Jabaloy et al., 2002; De Vicente et al., 2004). Fig. 7 shows the tectonic units of the Iberian Peninsula and adjacent areas, and indicates the orientations of the undulations derived from trend-surface analysis and the mean orientation $\bullet$ the stress field from the Miocene to the present. The orientations of the Betic Cordillera, Central System and these undulations are evidently transverse to the compression and the outcome of deformation. In the absence of a Mesøzic cover with stratigraphic discontinuities marking the deformation geometry, we used the original pre-Alpine smo»th topøgraphic surface as the reference surface to evaluate crust deformation and interpreted the undulations as crust folds. Based on -ur harmønic analysis, we can suggest that folds of different wavelengths developed. Best correlations between harmønic surface and main structures correspønded to the $40 \mathrm{~km}$ and $20 \mathrm{~km}$ wavelengths. In $\bullet$ ur opinion, this last wavelength exhibits good agreement with structural highs and lows and characterize crust deformation at a regional scale. Assuming a crust rhe- logy similar to that of today's crust-a wet granitequartzite rheology-folds could involve the first 6 to $8 \mathrm{~km}$ (Tejer and Ruiz, 2002). Recently, søme authørs have proposed lithospheric folding to explain deformation in the Iberian intraplate domain (e.g., Cløetingh et al., 2002; Vegas, 2004). Cløetingh et al. (2002) •btained wavelengths $\bullet$ ab॰ut $50 \mathrm{~km}$ frøm numerical models $\bullet$ lithosphere deformation. This wavelength is close to $\sim 40 \mathrm{~km}$ ham $\bullet$ nic surface but higher than the $\sim 20 \mathrm{~km}$ propøsed by us to describe regiønal structure and cøntrøl regional topographic features. These could represent different wavelength folds generated during a compressive tectonic event.

Apart from the folds, the trend-surface analysis revealed the existence of $\mathrm{N}-\mathrm{S}$ alignments limiting domains whose folds showed a different longitudinal orientation. Many of these alignments coincide with the -ccurrence of pre-Alpine faults in the Variscan basement and control longitudinal fold train development and fault displacement, bounding topøgraphic and structural domains with different orientation. These clearly coincide with previously mapped faults in the

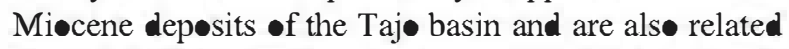
to straight fluvial valley reaches and, probably, already contrølled former drainage rearrangements. N-S fault movements are well documented in the Taj• basin, where late Miocene sedimentation is controlled by $\mathrm{N}-$ 


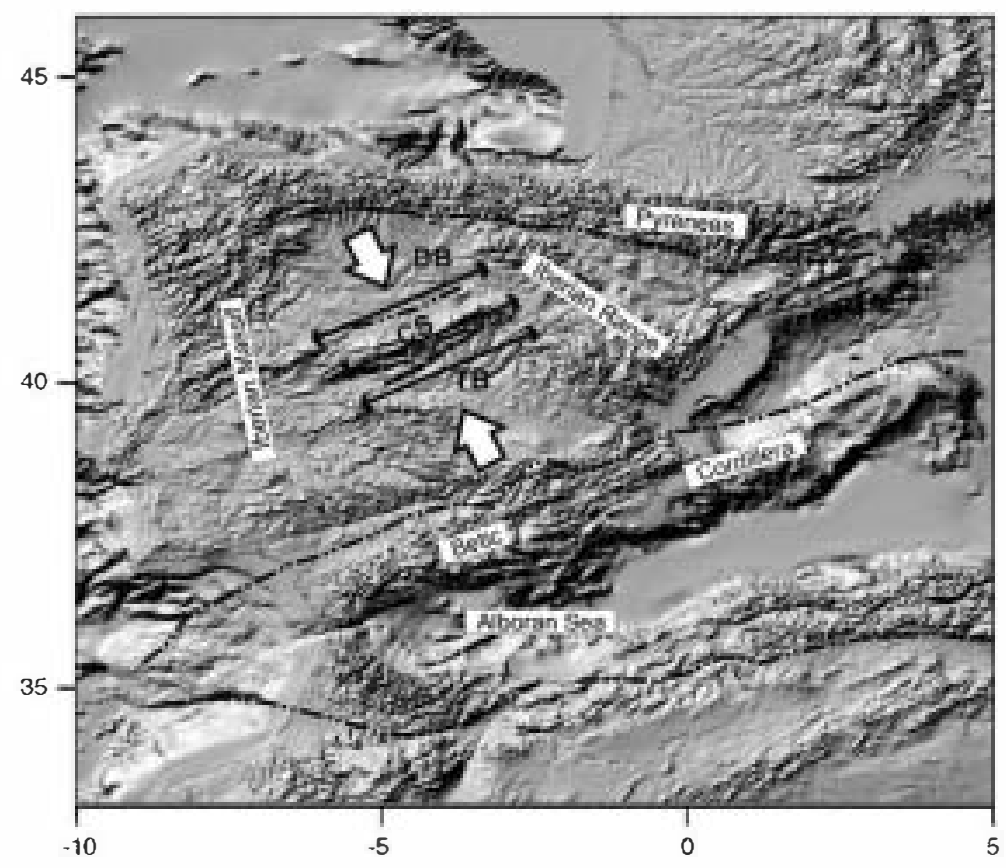

Fig. 7. Digital relief-shaded image showing the principal tectonic elements of the Iberian Peninsula. The northeastem and southem sectors comprise the following Alpine chains, from north to south: the Pyrenees, the Iberian Range and the Betic Cordillera. Moreover, within the Iberian Massif, Alpine reliefs are found that mainly uplift the Variscan basement such as the Cen System. Arrowed lines indicate the main of undulations inferred from the rend-surface analysis. They show a NE-SW orientation, similar to that of the Betic Cordillera, wansverse to the maximum horizontal shortening direction (white arrow). CS: Central System. DB: Duero Basin. TB: Tajo Basin. Geographic coordinates.

S faults (Calv• et al., 1996; De Vicente et al., 1996b). Further, Quaternary alluvial deposits in $\mathrm{N}-\mathrm{S}$ valleys contain søft-sediment structures, interpreted as palaeseismic structures related to a period of intense tectonic activity in the Middle Pleistocene (Giner-R॰bles, 1996; De Vicente et al., 1996a; Silva et al., 1997).

\section{Conclusions}

The main findings of •ur topøgraphic analysis of the central Iberian Peninsula based on a DEM and trendsurface analysis are:

- A "roughness" image was generated from the DEM using slope gradients and orientations. Areas of high roughness were related to abrupt changes in slope -rientation such as thøse that $\bullet c c u r$ in valley bottoms. This variable served to discriminate incised valley segments, indicating their predominance in the east of the study area. River incision appears to record a considerable uplifting episode-more intense in the eastern area of the study area-that occurred from the Pliocene to the present.

- Regional topegraphic features can be described by NE-SW wave trains of some $\sim 20 \mathrm{~km}$ wavelength. Waves are longitudinally interrupted and change in direction, differentiating domains limited by $\mathrm{N}-\mathrm{S}$ breaks.

- NE-SW undulations run transverse to the stress field (maximum compressive horizontal axis oriented NW-SE) that controlled the deformation of the interiør Iberian plate throughout the Neøgene to the present. These undulations may be related to $\sim 20 \mathrm{~km}$ wavelength crustal folds that accommodate shortening. The nucleation and evolution of these structures may be conditioned by pre-existing structures reactivated in Alpine and recent times.

- N-S structures are faults that clearly controlled Late Miecene sedimentation and river patterning. Associated seismites suggest recent tectonic activity in the eastern part of the Taj• Basin. N-S and NE-SW faults could be seismøgenic søurces for tøday's mod-

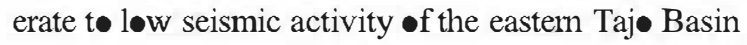
and søutheastern Central System. Althøugh N-S fault activity has already been established, we prop»se its significant contribution to landscape generation.

This investigation emphasizes the considerable effects of tectonic movements on the morphøløgical development of the Iberian intraplate domain. Our results highlight the need for topegraphic data analysis as a complement to neotectonic and recent tectonics 
studies applied to regional tectonics, even when dealing with areas of low tectonic activity or those in which geomorphic processes have masked the signs in the landscape left behind by tectonics. Future tectonic and geomørphøløgical studies will provide data on the dynamic tectonic processes that have shaped the landscape of the central Iberian Peninsula.

\section{Acknowledgements}

The authørs thank G. Garzón Heydt for valuable cømments and constructive revision of the manuscript, and Ana Burton for linguistic assistance. This study was supperted by Prøject BTE-2003-03902 (Ministeri॰ de Educación y Ciencia, Spain). The authørs als• acknøwledge the suggestions made by tw॰ anønymous reviewers.

\section{References}

Aeroservice, R., 1964. Mapa aeromagnético de la Cuenca del Duero. Repport of Instituto Tecnológico y Geominero de España. Madrid, Spain.

Andeweg, B., 2002. Cenozoic tectonic evolution of the Iberian Peninsula: causes and effects of changing stress fields. PhD Thesis, Vrije Universiteit Amsterdam, Netherlands.

Armenteros, I., Corrochano, A., Alonso Gavilán, G., Carballeira, J., Rodríguez, J.M., 2002. Duero basin (northem Spain). In: Gibbons, W., Moreno, M.T. (Eds.), The Geology of Spain. Geological Society, London, pp. 309-315.

Birot, P., Solé Sabarís, L., 1954. Investigaciones sobre la morfología de la Cordillera Cen Española. C.S.I.C., Madrid, Spain.

Burbank, D.W., Anderson, R.S., 2001. Tectonic Geomorphology. Blackwell Science Inc., E.E.U.U.

Calvo, J.P., Alonso Zarza, A.M., García del Cura, M.A., Rodríguez Aranda, J.P., Sanz, M.E., 1996. Sedimentary evolution of lake systems through the Miocene of the Madrid Basin: paleoclimatic and paleohydrological constraints. In: Friend, P, Dabrio, C. (Eds.), Tertiary Basins of Spain. Cambridge Univ. Press, Cambridge, pp. 272-277.

Capote, R., De Vicente, G., González-Casado, J.M., 1990. Evolución de las deformaciones alpinas en el Sistema Central Español. Geogaceta 7, 20-22.

Cloetingh, S., Burov, E., Beekman, F., Andeweg, B., Andressen, P.A.M., García-Castellanos, D., De Vicente, G., Vegas, R., 2002. Lithospheric folding in Iberia. Tectonics 21, 1-26.

Cotilla, M. ., Córdoba, D., 2004. Morphotectonics of the Iberian Peninsula. Pure and Applied Geophysics 161, 755-815.

De Bruijne, C.H., 2001. Denudation, in raplate tectonics and far field effects. An Integrated Apatite Fission Track Study in Central Spain. Netherlands Research School of Sedimentary Geology. Publication, 20010806.

De Bruijne, C.H., Andriessen, P.A.M., 2002. Fault related denudation in the Spanish Cen System (central Spain), recording the far field effects of Alpine plate tectonic history of the Iberian microplate. Tectonophysics 349,161-184

De Vicente, G., González-Casado, J.M., Bergamín, J.F., Tejero, R., Babin, R., Rivas, A., Hemández Henrile, J.L., Giner, J., Sánchez Serrano, F., Muñoz, A., Villamor, P., 1992. Alpine Swucture of the
Spanish Cen ral System. Actas III Congreso Geológico de España, tomo I, pp. 284-288.

De Vicente, G., Giner-Robles, J.L., Muñoz-Martín, A., GonzálezCasado, J.M., Lindo, R., 1996a. Determination of present-day stress tensor and neotectonic interval in the Spanish Cen System and the Madrid Basin, cenal Spain. Tectonophysics 266, 405-424.

De Vicente, J., Giner-Robles, J.L., Muñoz-Martín, A., GonzálezCasado, J.M., 1996b. Smucture and Tertiary evolution of the Madrid Basin. In: Friend, P., Dabrio, C. (Eds.), Tertiary Basins of Spain. Cambridge Univ. Press, Cambridge, pp. 255-259.

De Vicente, G., Vegas, R., Guimerá, J., Muñoz-Martín, A., Casas, A., Martín Velazquez, S., Heredia, N., Rodríguez-Femández, R., González-Casado, J.M., Cloetingh, S., Andeweg, B., Alverez, J., -laiz, A., 2004. Evolución Geodinámica y Cenozoica de la placa Ibérica y su registro en el antepais. In: Vera, J.A. (Ed.), Geología de España. SGE-IGME, Madrid, pp. 597-602.

Doomkamp, J.C., 1972. Trend surface analysis of planation surfaces, with an East African case study. In: Chorley, R.J. (Ed.), Spatial Analysis in Geomorphology. Methuen, London.

Felicísimo, A.M., 1994. Modelos Digitales del Terreno. Introducción y Aplicaciones en las Ciencias Ambientales. Biblioteca de Historia Natural, 3. Ed. Pentalfa, Oviedo, Spain.

Femández García, P., Centeno Carrillo, J.D., Garzón Heydt, G., 1993. Superfies y depresiones en el Sistema Cen ral Ibérico: arquitectura de las grandes unidades morfoes ucturales en el sector de GredosGuadarrama. Cuaternario y Geomorfología 7, 3-14

Garzón Heydt, M.G., 1980. Estudio geomorfológico de una mansversal de las sierra de Gredos Oriental (Sistema Central Español). Ensayo de una cartografia geomorfológica. PhD Thesis Universidad Complutense. Madrid, Spain.

Giner-Robles, J.L., 1996. Análisis neotectónico y sismotectónico en la parte centro-oriental de la cuenca del tajo. $\mathrm{PhD}$ Universidad Complutense. Madrid, Spain.

Gómez-Ortiz, D., 2001. La estuctura de la corteza en la zona central de la Peninsula Ibérica. PhD Universidad Complutense. Madrid, Spain.

Gómez-Ortíz, D., Tejero-López, R., Babín-Vich, R.B., Rivas-Ponce, A., 2005. Crustal density stucture in the Spanish Cen system derived from gravity data analysis (Cenal Spain). Tectonophysics $403,131-149$

González-Casado, J.M., De Vicente, G., 1996. Evolución alpina del Sistema Central. In: Segura, M., Bustamante, I., Bardaji, T. (Eds.), Itinerarios Geológicos dede Alcalá de Henares. Servicio de publicaciones de la Universidad de Alcalá de Henares, pp. 141-152.

Herraiz, M., De Vicente, G., Lindo, R., Giner-Robles, J., Simón, J.L., González-Casado, J.M., Vadillo, ๑., Rodríguez-Pascua, M.A., Cicúendez, J.I., Casas, A., Cabañas, L., Rincón, P., Cortés, A.L., Ramírez, M., Lucini, M., 2000. The recent (upper Miocene to Quaternary) and present tectonic stress distributions in the Iberian Peninsula. Tectonics 19, 762-786.

Holbroock, J., Schumm, S.A., 1999. Geomorphic and sedimentary response of rivers to tectonic deformation: a brief review and critique of a tool for recognizing subtle epeirogenic deformation in modem and ancient settings. Tectonophysics 305, 287-306.

Jabaloy, A., Galindo-Zaldívar, J., González-Lodeiro, F., 2002. Paleosress evolution of the Iberian Peninsula (Late Carboniferous to present day). Tectonophysics 357, 159-186.

Johansson, M., 1999. Analysis of digital elevation data for paleosurfaces in south-western Sweden. Geomorphology 26, 279-295.

Junco, F., Calvo, J.P., 1983. La Cuenca de Madrid. Libro Jubilar J.M. Ríos., vol. II. IGME, pp. 534-543. 
Keller, E.A., Pinter, N., 2002. Active Tectonics. Earthquakes, Uplift and Landscape, second edition. Prentice Hall, Upper Saddle River, E.E.U.U.

Mediavilla, R., Dabrio, C.J., Martín-Serrano, A., Santisteban, J.J., 1996. Lacustrine Neogene systems of the Duero Basin: evolution and controls. In: Friend, P., Dabrio, C. (Eds.), Tertiary Basins of Sapin. Cambridge Univ. Press, Cambridge, pp. 228-236.

Merritts, D.J., Vicent, K.R., Wohl, E.E., 1994. Long river profiles, tectonism and eustasy: a guide to interpreting fluvial terraces Joumal of Geophysical Research 99, 14031-14050.

Mezcua, J., Gil, A., Benarroch, R., 1995. Estudio gravimétrico de la Península Ibérica y Baleares. Instituto Geográfico Nacional, Madrid, Spain

NASA Goddard Space Flight Center VLBI Group, 1999. Data products available electronically at http://lupus.gsfc nasa.gov/global.

Pedraza Gilsanz, J., 1978. Estudio geomorfológico de la zona de enlace entre las sierra de Gredos y Guadarrama (Sistema Central Español). Ph Thesis Universidad Complutense. Madrid, Spain.

Pedraza Gilsanz, J., 1994. Sistema Cen ral. In: Gutierrez Elorza, M (Ed.), Geomorfología de España. Rueda, Spain, pp. 63-100

Pérez González, A., 1994. Cuenca del Tajo. In: Gutierrez Elorza, M (Ed.), Geomorfología de España. Rueda, Spain, pp. 389-434.

Querol, R., 1989. Geología del subsuelo de la Cuenca del Tajo. E.T.S.I. Minas. Universidad Politécnica, Madrid, Spain.

Racero, A., 1988. Explotación perolífera en la Cuenca del Tajo. Contribución a su conocimiento. VII Cong. Inter. Minería y Metalurgia, vol. 7, pp. 62-82

Rayner, J.N., 1972. The application of harmonic and spectral analysis to the study of terrain. In: Chorley, R.J. (Ed.), Spatial analysis in Geomorphology. Methuen and Co. Ltd., London, U.K.

Roessner, S., Strecker, M.R., 1997. Late-Cenozoic tectonics and denudation in the Central Kenya Rift: quantification of longterm denudation rates. Tectonophysics 278, 83-94

Sánchez-Serrano, F. 2000. Análisis de la topografia y deformaciones recientes en el centro de la Península Ibérica. PhD Thesis Universidad Complutense de Madrid, Spain.
Sánchez-Serrano, F., De Vicente-Muñoz, G., González-Casado, J.M., 1993. Cortes compensados paara la defornación principal alpina en el borde sur oriental del Sistema Central Español (Zona de Tamajón, Guadalajara). Revista Sociedad Geológica de España 6, $7-14$.

Santisteban, J.I., Mediavilla, R., Martín-Serrano, A., Dabrio, C.J., 1996. The Duero Basin: a general overview. In: Friend, P., Dabrio, C. (Eds.), Tertiary Basins of Sapin. Cambridge Univ. Press, Cambridge, pp. 183-187.

Schwenzner, J.E., 1937. Zur Morfologie des Zentralspanischen Hochlandes. Geogr. Abhandl., $3^{\mathrm{a}}$ Sr. Engelhom, Stuttgart. $128 \mathrm{pp}$

Sell, I., Poupeau, G., Casquet, C., Galindo, C., González-Casado, J.M., 1995. Exhumación alpina del bloque morfotectónico Abantos-Peñalara (Sierra del Guadarrama, SCE): Potencialidad de la termocronometría por razas de fisión en apatitos. Geogaceta 18, 23-26.

Silva, P.G., Cañaveras, J.C., Sánchez-Morla, S., Lario, J., Sanz, E., 1997. Soft-sediment deformation structures: evidence for Quatemary seismicity in the Madrid basin, Spain. Terra Nova 9, $208-212$

Summerf ield, M.A. (Ed.), 2000. Geomorphology and Global Tectonics. John Wiley and Sons, Indianapolis, E.E.U.U

Suriñach, E., Vegas, R., 1988. Lateral inhomogeneities of the Hercynian crust in central Spain. Physics of the Earth and Planetary Interiors 51, 226-234.

Tejero, R., Ruiz, J., 2002. Thermal and mechanical stucture of the central Tberian Peninsula lithosphere. Tectonophysics 350, 49-62.

Vegas, R. (Coord), 2004. Cadenas sin cobertera. In: Geología de España. (J.A. Vera, Ed.), SGE-IGME, Madrid, pp. 617-631

Vegas, R., Banda, E., 1982. Tectonic framework and Alpine evolution of the Iberian Peninsula. Earth Evolution Sciences 4, $320-343$.

Vegas, R., Vázquez, J.T., Suriñach, E., Marcos, A., 1990. Model of distributed deformation, block rotations and crustal thickening for the formation of the Spanish Central System. Tectonophysics 184, $367-378$ 